\title{
A Technique for Estimating Rangeland Canopy-Gap Size Distributions From High-Resolution Digital Imagery
}

\author{
Jason W. Karl, ${ }^{1}$ Michael C. Duniway, ${ }^{2}$ and T. Scott Schrader ${ }^{3}$ \\ Authors are ${ }^{1}$ Research Ecologist, and ${ }^{2}$ Research Soil Scientist, and ${ }^{3}$ Senior GIS Specialist, USDA-ARS Jornada Experimental Range, \\ Las Cruces, NM 84532, USA.
}

\begin{abstract}
The amount and distribution of gaps in vegetation canopy is a useful indicator of multiple ecosystem processes and functions. In this paper, we describe a semiautomated approach for estimating canopy-gap size distributions in rangelands from highresolution (HR) digital images using image interpretation by observers and statistical image classification techniques. We considered two different classification methods (maximum-likelihood classification and logistic regression) and both pixelbased and object-based approaches to estimate canopy-gap size distributions from 2- to 3-cm resolution UltraCamX color infrared aerial photographs for arid and semiarid shrub sites in Idaho, Nevada, and New Mexico. We compare our image-based estimates to field-based measurements for the study sites. Generally, percent of input points correctly classified and kappa coefficients of agreement for plot image classifications was very high. Plots with low kappa values yielded canopy gap estimates that were very different from field-based estimates. We found a strong relationship $\left(R^{2}>0.9\right.$ for all four methods evaluated) between image- and field-based estimates of the total percent of the plot in canopy gaps greater than $50 \mathrm{~cm}$ for plots with a classification kappa of greater than 0.5 . Performance of the remote sensing techniques varied for small canopy gaps (25 to $50 \mathrm{~cm})$ but were very similar for moderate $(50$ to $200 \mathrm{~cm})$ and large $(>200 \mathrm{~cm})$ canopy gaps. Our results demonstrate that canopy-gap size distributions can be reliably estimated from HR imagery in a variety of plant community types. Additionally, we suggest that classification goodness-of-fit measures are a potentially useful tool for identifying and screening out plots where precision of estimates from imagery may be low. We conclude that classification of HR imagery based on observer-interpreted training points and image classification is a viable technique for estimating canopy gap size distributions. Our results are consistent with other research that has looked at the ability to derive monitoring indicators from HR imagery.
\end{abstract}

\section{Resumen}

La cantidad y distribución de espacios en la cubierta vegetal es un útil indicador de múltiples procesos y funciones del ecosistema. En este artículo describimos un enfoque semiautomático para estimar la distribución del tamaño del espacio de la cubierta en pastizales de imágenes digitales de alta resolución usando interpretación de imagen por observadores y técnicas estadísticas de clasificación de imagen. Consideramos dos diferentes métodos de clasificación (clasificación de máxima probabilidad y regresión logística) y enfoques basado en pixel y basado en objetivo para estimar la distribución del tamaño del espacio de la cubierta de fotografías aéreas infrarrojas con 2-3 cm de resolución UltraCamX para sitios de matorral áridos y semi áridos en Idaho, Nevada y Nuevo México. Comparamos nuestras estimaciones basadas en imagen con medidas basadas en campo para los sitios de estudio. Generalmente, el porcentaje de puntos clasificados correctamente y los coeficientes de acuerdo kappa de la clasificación de imagen de parcela fue muy alto. Parcelas con valores bajos de kappa resultaron con estimaciones de espacios de cubierta que fueron muy diferentes de los estimados basados en campo. Encontramos una fuerte relación $\left(R^{2}>0.9\right.$ en los cuatro métodos evaluados) entre imágenes y estimaciones basadas en campo del porcentaje total de la parcela con espacios de cubierta mayores de $50 \mathrm{~cm}$ por parcela con una clasificación kappa mayor que 0.5 . El desempeño de las técnicas de sensores remotos varia de espacios pequeños de cubierta $(25 \mathrm{a} 50 \mathrm{~cm})$ pero fueron muy similares de espacios de cubierta moderado $(50 \mathrm{a} 200 \mathrm{~cm})$ a grande $(>200 \mathrm{~cm})$. Nuestros resultados demuestran que la distribución de espacios de cubierta puede ser estimada con certeza de imágenes de alta resolución en diversos tipos de comunidades de plantas. En suma, sugerimos que las medidas de clasificación de bondad de ajuste son una herramienta potencialmente útil para identificar y explorar parcelas donde la precisión de estimación de imágenes podrá ser baja. Concluimos que la clasificación de imágenes de alta resolución basadas en puntos de entrenamiento de observar-interpretar y clasificación de imágenes es una técnica viable para estimar la distribución del tamaño del espacio de cubierta. Nuestros resultados son consistentes con otra investigación que ha buscado la habilidad de derivar indicadores de monitoreo de imágenes de alta resolución.

Key Words: digital aerial photography, image classification, photo interpretation, remote sensing

Research was funded in part by the USDA-NRCS's National Resource Inventory Conservation Effects Assessment Project and the National Park Service Lake Mead National Recreation Area and Mojave Desert Network.

Correspondence: Jason W. Karl, USDA-ARS Jornada Experimental Range, PO Box 30003, MSC 3JER, New Mexico State University, Las Cruces, NM 88003-8003, USA. Email: jkarl@nmsu.edu Current address: Michael C. Duniway, Research Ecologist, US Geological Survey, Southwest Biological Science Center, Canyonlands Research Station, Moab, UT 84532, USA.

Manuscript received 3 January 2011; manuscript accepted 31 October 2011. 


\section{INTRODUCTION}

There is a critical need for quantitative information on the ability of rangelands to sustain basic ecological functions (e.g., soil productivity, water infiltration) and produce ecosystem services (National Research Council 1994; Herrick et al. 2010). In grassland, shrubland, and savannah ecosystems, basic measurements of the amount and distribution of vegetative and bare ground cover are useful indicators for assessing ecosystem function and monitoring change over time. The amount and distribution of gaps in vegetation canopy (where canopy is defined as ground surface covered by a vertical projection of living or dead plant material; Herrick et al. 2009) is a particularly useful indicator of multiple ecosystem processes and functions, including erosion by wind and water, wildlife habitat suitability, grazing impacts, and susceptibility to invasive species (Gillette 1977; Schlesinger et al. 1990; Milton et al. 1994; Pierson et al. 1994; Bautista et al. 2007; Okin 2008; Herrick et al. 2009). Additionally, the amount and distribution of vegetation canopy gaps has been used to identify sites at risk of crossing a threshold to an undesired state (Bestelmeyer et al. 2009).

The size of canopy gaps on a site is an important indicator because it is directly related to ecosystem processes and functions. For example, Okin (2008) found that the best vegetation structure metric for predicting wind erosion was the ratio of average canopy gap size to canopy height, suggesting canopy gap size distribution for wind erosion susceptibility will differ among communities depending on vegetation stature. Modeled shear stresses and horizontal sediment fluxes in canopy gaps greatly increased at gap to height ratios greater than approximately one. Thus, critical canopy gap sizes should correspond to the height of vegetation. In grassland communities with short stature vegetation, $50 \mathrm{~cm}$ could be an appropriate critical gap size. In taller shrub or savanna systems, the critical gap size would be much larger $(\sim 200 \mathrm{~cm})$. Similarly, Pierson et al. (1994) and Bautista et al. (2007) found that water erosion increased with amount and connectivity of bare ground but appeared to have less of a threshold response to gap distributions than observed with wind erosion. Therefore, it is important that a method for measuring canopy gaps is capable of accurately estimating gaps of various sizes (e.g., $<50 \mathrm{~cm}, 50$ $200 \mathrm{~cm}$, and $>200 \mathrm{~cm}$ ).

To date, however, broad-scale quantitative data on vegetative cover, particularly canopy gap size distributions, are generally lacking due to the high costs of measuring these indicators in the field. Estimates of total or fractional vegetative cover can be reliably produced from satellite or aerial imagery (Knapp et al. 1990; Hansen and Ostler 2001; e.g., Booth and Tueller 2003; Hunt et al. 2003; Marsett et al. 2006; Karl 2010), but most common remote-sensing imagery is not of high enough spatial resolution to measure the sizes of canopy gaps that are important leading indicators for land managers (i.e., canopy gaps as small as $50-\mathrm{cm}$ across). This critical limitation has largely relegated the measurement of canopy gap distributions to field-data collection efforts and may hinder a broader use of canopy gap data for predicting ecosystem processes like wind and water erosion or attributes such as wildlife habitat suitability.

Interpretation or classification of high-resolution (HR; i.e., pixels with a ground-separation distance $[\mathrm{GSD}]<1 \mathrm{~m}$ but $>1 \mathrm{~cm}$ ) and very-high-resolution (VHR; i.e., pixels with $\mathrm{GSD}<1 \mathrm{~cm}$ ) aerial images has been demonstrated to be a viable option for collecting information on vegetation cover across a variety of ecosystems (Hansen and Ostler 2001; Fensham et al. 2002; Booth and Tueller 2003; Booth et al. 2005a; Luscier et al. 2006; Booth and Cox 2008; Duniway et al. in press). Estimating the presence and distribution of canopy gaps from HR and VHR aerial images has been more limited, however, especially in nonforested ecosystems. Fox et al. (2000) found that forest canopy gaps mapped from HR imagery were more accurate than field-mapped canopy gaps. McGlynn and Okin (2006) used coarser 1-m resolution aerial photographs to map the distribution of shrubs vs. nonshrubs in a desert shrubland but did not compare their results to field measurements. So while interpretation of HR and VHR imagery appears to be a promising technology for estimating canopy gap distributions, the factors affecting the accuracy and precision of such estimates are largely unknown.

While HR and VHR imagery is becoming more widely available and affordable, it is currently expensive enough to acquire, store, and analyze that it is typically used within a sampling framework. Rather than acquire continuous HR or VHR image coverage of an area, images are collected for specific locations selected according to a sample design, and statistical inferences are drawn to a larger area. Efforts such as the Natural Resource Conservation Service's National Resource Inventory (NRI), a national-level monitoring program, are already collecting HR imagery $(\sim 30 \mathrm{~cm}$ GSD) for thousands of sampling locations annually for reference and to extract general information on land use, but standard estimates of vegetation cover are not made from these images. A method for extracting additional information like canopy gap size distributions from these images could add value to programs like NRI.

In this paper, we describe a semiautomated approach for estimating canopy-gap size distributions from HR images using image interpretation by observers and statistical image classification techniques. We consider two different classification methods (maximum-likelihood [ML] classification and logistic regression [LR]) in using both pixel-based and object-based approaches and compare our results to field canopy gap measurements. We demonstrate this method for multiple study areas in the western United States where gaps in vegetation are of concern, representing a range of plant communities and gap size distributions. Finally, we discuss the benefits and limitations of this technique and make recommendations on the level and type of field and expert-observer input information needed for accurate and precise canopy gap estimates in different ecosystems.

\section{STUDY AREA}

For this study we used a subset of the aerial images and field data collected by Duniway et al. (in press). We selected three sites in each of three states: Idaho, Nevada, and New Mexico (Table 1). To assess the ability to extract canopy gap information from HR digital aerial photographs, we selected study sites to represent a broad range of plant communities and canopy gap amounts within grazing lands of the western United States (see Figure 1). Vegetation on the sites was a mix of arid and semiarid shrubland communities common to the Owyhee High Plateaus; Mojave Desert; and Southern Desertic Basins, 
Table 1. Locations of study sites and acquisition dates of the color infrared digital aerial photographs used in this study.

\begin{tabular}{|c|c|c|c|c|c|}
\hline Study area & Site & Geographic coordinates & Average elevation, $\mathrm{m}$ & Average annual precipitation, ${ }^{1} \mathrm{~cm}$ & Photo acquisition dates \\
\hline \multirow[t]{3}{*}{ Idaho } & 1 & $\begin{array}{l}\text { Lat } 43^{\circ} 12^{\prime} 35.9^{\prime \prime} \mathrm{N}, \\
\quad \text { long } 116^{\circ} 44^{\prime} 15.6^{\prime \prime} \mathrm{W}\end{array}$ & 1227 & 28 & 27 August 2008 \\
\hline & 2 & $\begin{array}{l}\text { Lat } 43^{\circ} 6^{\prime} 32.1^{\prime \prime} \mathrm{N} \text {, } \\
\quad \text { Iong } 116^{\circ} 46^{\prime} 33.8^{\prime \prime} \mathrm{W}\end{array}$ & 1629 & 69 & 27 August 2008 \\
\hline & 3 & $\begin{array}{l}\text { Lat } 43^{\circ} 3^{\prime} 58.1^{\prime \prime} \mathrm{N} \text {, } \\
\quad \text { long } 116^{\circ} 45^{\prime} 23.2^{\prime \prime} \mathrm{W}\end{array}$ & 2082 & 89 & 27 August 2008 \\
\hline \multirow[t]{3}{*}{ Nevada } & 1 & $\begin{array}{l}\text { Lat } 36^{\circ} 21^{\prime} 45.4^{\prime \prime} \mathrm{N}, \\
\quad \text { Iong } 114^{\circ} 25^{\prime} 1.9^{\prime \prime} \mathrm{W}\end{array}$ & 366 & 15 & 17 March 2009 \\
\hline & 2 & $\begin{array}{l}\text { Lat } 36^{\circ} 22^{\prime} 12.5^{\prime \prime} \mathrm{N}, \\
\quad \text { long } 114^{\circ} 26^{\prime} 50.9^{\prime \prime} \mathrm{W}\end{array}$ & 470 & 16 & 17 March 2009 \\
\hline & 3 & $\begin{array}{l}\text { Lat } 35^{\circ} 17^{\prime} 50.7^{\prime \prime} \mathrm{N} \text {, } \\
\quad \text { long } 115^{\circ} 33^{\prime} 14.0^{\prime \prime} \mathrm{W}\end{array}$ & 1601 & 24 & 17 March 2009 \\
\hline \multirow[t]{3}{*}{ New Mexico } & 1 & $\begin{array}{l}\text { Lat } 32^{\circ} 34^{\prime} 37.0^{\prime \prime} \mathrm{N} \text {, } \\
\quad \text { Iong } 106^{\circ} 0^{\prime} 42.0^{\prime \prime} \mathrm{W}\end{array}$ & 1230 & 26 & 23 August 2008 \\
\hline & 2 & $\begin{array}{l}\text { Lat } 32^{\circ} 29^{\prime} 38.8^{\prime \prime} \mathrm{N} \text {, } \\
\quad \text { long } 105^{\circ} 40^{\prime} 59.7^{\prime \prime} \mathrm{W}\end{array}$ & 1641 & 48 & 23 August 2008 \\
\hline & 3 & $\begin{array}{l}\text { Lat } 32^{\circ} 22^{\prime} 33.8^{\prime \prime} \mathrm{N} \text {, } \\
\quad \text { long } 105^{\circ} 39^{\prime} 25.6^{\prime \prime} \mathrm{W}\end{array}$ & 1440 & 37 & 23 August 2008 \\
\hline
\end{tabular}

${ }^{1}$ Average annual precipitation from 1971 to 2000 from the 800-m resolution US Average Annual Precipitation layer, PRISM Group at Oregon State University (http://prism.oregonstate.edu, Accessed July 22, 2011).

Plains, and Mountains major land resource areas (Natural Resources Conservation Service 2006). Site elevations ranged from $366 \mathrm{~m}$ to $2082 \mathrm{~m}$, and average annual precipitation ranged from $15 \mathrm{~cm}$ to $88 \mathrm{~cm}$ (Table 1 ).

Three $50 \times 50 \mathrm{~m}$ sampling plots were established within each site using a nested approach similar to that used by the NRI (Nusser and Goebel 1997). This gave a total of 27 plots (three plots per site, three sites per state, and three states). Sites and plots were selected nonrandomly to capture a range of vegetation and bare ground cover conditions. See Duniway et al. (in press) for more on site and plot selection.

\section{METHODS}

\section{Image Acquisition and Processing}

For each study plot (three plots per site, three sites per state), color-infrared (red, green, blue, and near-infrared spectral bands) imagery was acquired using an UltraCamX (Vexcel Imaging, Graz, Austria) flown at approximately 1000 feet above ground level. Flying at this altitude with this sensor yielded a GSD of $2 \mathrm{~cm}$ to $3 \mathrm{~cm}$ and an image with a ground footprint of approximately $210 \times 330 \mathrm{~m}$. Imagery was collected within $2 \mathrm{~h}$ of solar noon to minimize the amount of shadow. Dates of image acquisition were timed, as closely as possible, to correspond to peak "greenness" of vegetation in each study area. All image acquisition, georeferencing, and orthorectification was completed by Aerographics Inc. (Salt Lake City, UT). The stated horizontal accuracy of the delivered products was less than $2 \mathrm{~m}$. Because the objective of this research was to determine if plot-level estimates of canopy-gap size distributions could be obtained through image analysis, and image-based virtual transects did not need to precisely align with field-based transects, this level of positional accuracy was acceptable.

\section{Image Interpretation and Classification}

Duniway et al. (in press) describe in detail the procedure for interpreting the image for each plot. Six 50-m virtual transects oriented north-to-south were spaced evenly across each plot image. Points were established every meter along the transects (50 points per transect, 300 per plot image). The image interpreter (i.e., observer), after having gone through an image interpretation training and calibration process, used a custom tool in ArcGIS 9.3 (Esri, http://www.esri.com) to evaluate each transect point at a fixed scale $(1: 40)$ and assign it to one of 10 predefined cover types (e.g., shrub, grass, litter, and soil). Interpreters were instructed to assign cover-type values to points in shadow only if they were confident in its cover type. Otherwise, points falling in shadows were coded as shadow. Because Duniway et al. (in press) were assessing betweenobserver variability, seven observers evaluated each plot image. For the purposes of our study, however, we used the majority decision of all seven observers for each transect point. In cases where no class had a clear majority (i.e., two or more classes tied), the class was assigned randomly from the competing classes. Cover type values were collapsed into canopy and noncanopy. These points, attributed with either canopy or noncanopy, became the training dataset for statistical classification of the plot images (Fig. A).

One of the objectives of this research was to compare pixelbased and object-based methods for estimating canopy-gap size distributions from imagery. Object-based image analysis (OBIA), a technique that groups adjacent, similar pixels together into polygons (i.e., objects) by minimizing local variance (Burnett and Blaschke 2003; Blaschke 2010), has repeatedly been shown to yield high accuracy classifications (Dorren et al. 2003; Wang et al. 2004; Karl and Maurer 2010a), especially with HR imagery (Laliberte et al. 2004; Laliberte and Rango 2009). With OBIA, the objects, not the image pixels, are the basic analysis unit. We segmented each plot image into objects 


\section{Site 1}
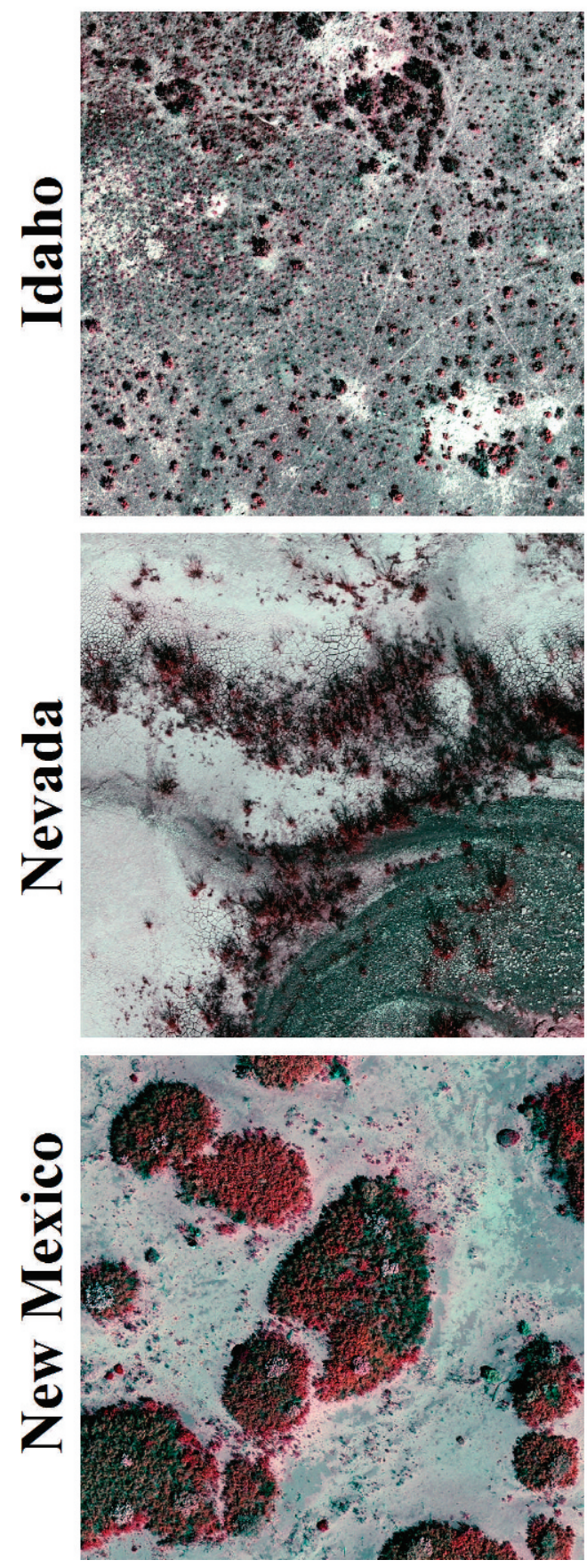

Site 2
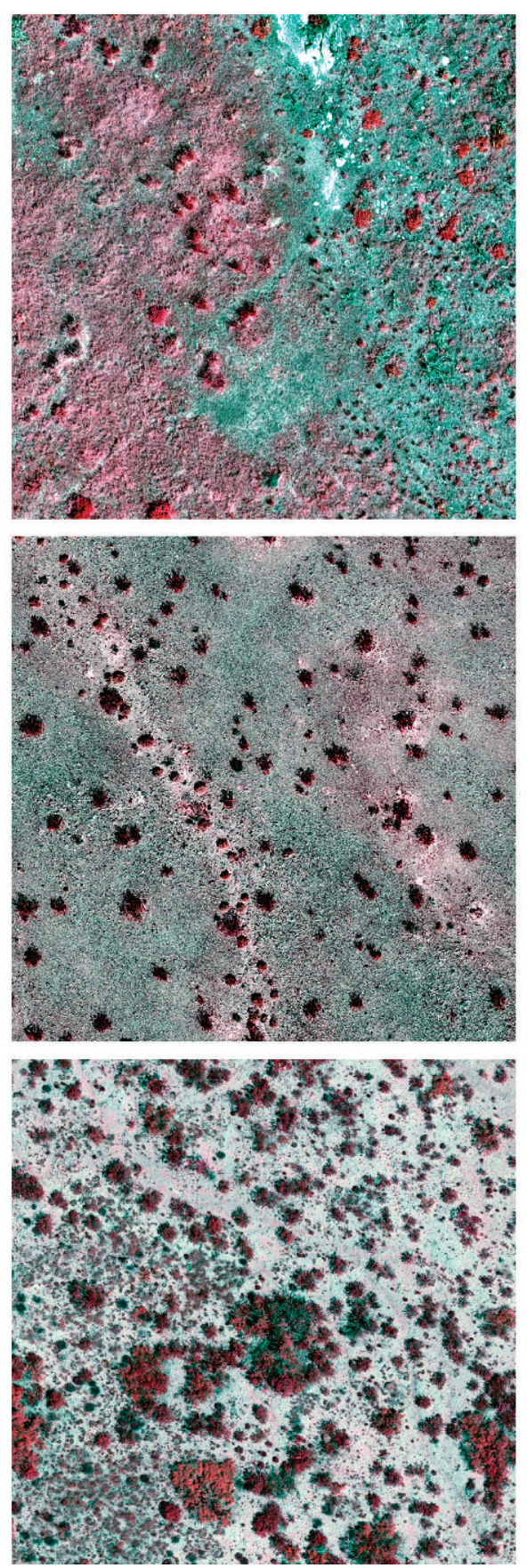

Site 3
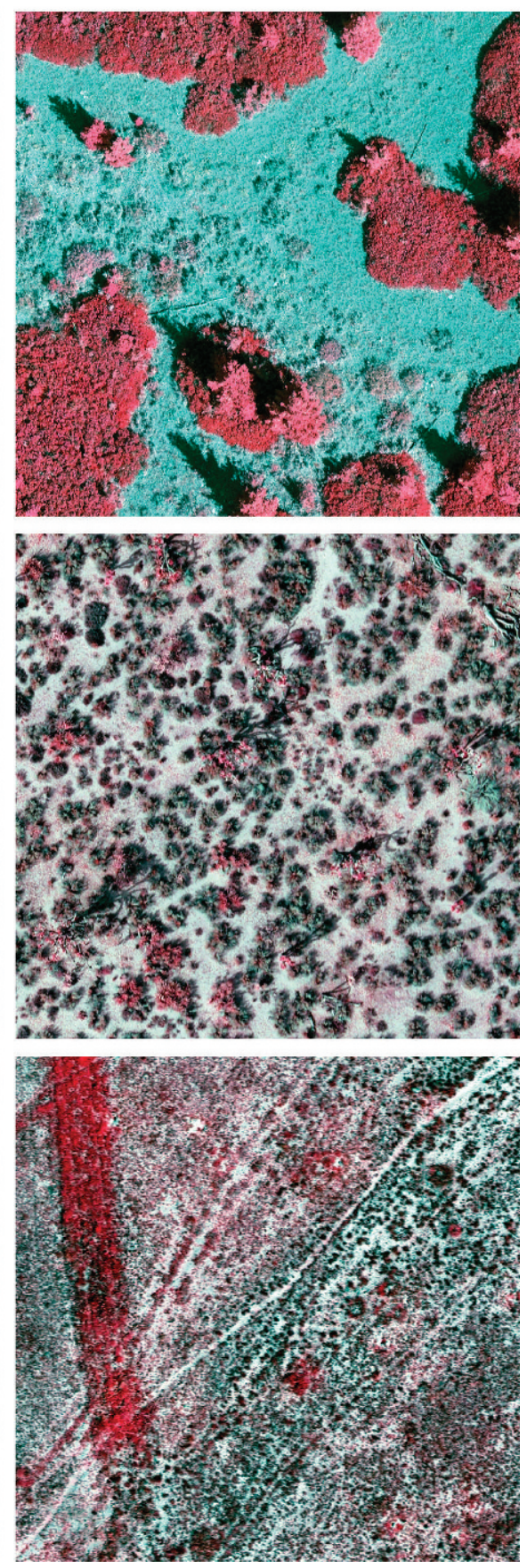

Figure 1. Examples of the high-resolution (HR; $2-\mathrm{cm}$ to $3-\mathrm{cm}$ resolution) digital images acquired for each plot in the study. A total of 27 images were considered for this study: three plots per site; three sites in Idaho, Nevada, and New Mexico. Images are displayed in color infrared. Sites were selected to represent a variety of arid and semiarid vegetation types common in western US rangelands (see Table 1).

using the eCognition Developer 8.0 (Trimble, http://www. ecognition.com) multiscale resolution segmentation process (scale parameter, 200; shape parameter: 0.1; compactness, $0.5)$. This yielded an average of 45540 objects with a median size of $159 \mathrm{~cm}^{2}$ per plot image. The mean and standard deviation of pixels within an object for each of the four image bands were calculated and used as independent variables in the image classifications.
For the pixel-based analysis, we performed a $5 \times 5$ cell moving window to calculate the average and standard deviation of pixels in a neighborhood around each image pixel. This did not change the native resolution of the image but allowed us to calculate independent variables for the pixelbased images to match the OBIA-segmented images. Also, while observers were instructed to interpret only the precise location under each transect point when assigning cover type 

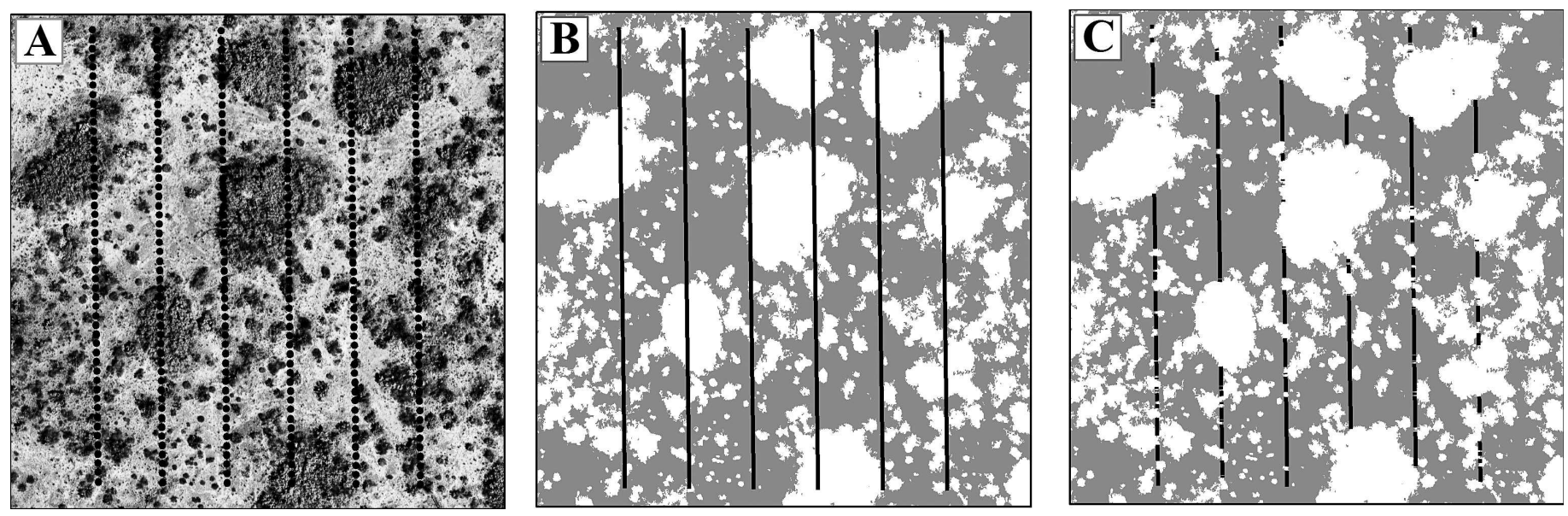

Figure 2. Diagram illustrating the process of classifying each plot image and calculating the canopy gaps from the virtual transects. A, Trained observers assigned a cover class to each of 300 points arranged into six 50-m transects. B, The cover classes were collapsed into canopy vs. noncanopy, and the points were used to classify the image using two approaches (object-segmentation and pixel-based) and two classification methods (logistic regression and maximum-likelihood classification). Gray areas represent the noncanopy class. C, Each classified image was intersected with the virtual transects, and segments of the noncanopy class greater than $25 \mathrm{~cm}$ in length were identified as canopy gaps. The proportion of the total transect length in canopy gaps of different sizes was calculated as the image-based canopy gap estimate.

values and not the area surrounding the point, in practice, due to the cartographic scale at which interpretation was taking place, assignment of cover types was likely based on a collection of image pixels.

Images for each plot were classified into two cover types (canopy and noncanopy) using two different methods: an ML classifier and LR. The 300 transect points attributed as canopy or noncanopy by image interpretation were used as training data for the classification. The ML classifier used the variance and covariance of image values that corresponded to sample locations to construct a sample distribution for each class. The probability of membership in each class is calculated for each pixels or object in the image and assigned to whichever class has the higher probability (Lillesand and Kiefer 1994). The ML classification for this study was accomplished using the ArcGIS MLClassify command.

LR is a statistical modeling technique that can be used to predict the probability of occurrence of an event or membership in a single class by fitting the data to a logit function. In our case, LR was used to predict the probability (ranging from 0.0 to 1.0) that a given pixel or image object belonged to the canopy or noncanopy class. By selecting a threshold probability value, a thematic map can be produced consisting of canopy and noncanopy classes. We constructed LR models predicting probability of membership in the noncanopy class and generated canopy vs. noncanopy layers for each plot image in $\mathrm{R}$ (software package version 2.10.1; R Development Core Team 2009). We used the 300 observer-evaluated points as dependent variables and the eight-image band values (mean and standard deviation of the original image bands) as independent variables. LR is a type of generalized linear regression model and assumes normality of input variables. We tested whether each input variable followed a normal distribution using a Wilk-Shapiro test (Royston 1982). We used a backward variable selection technique starting with all eight input variables to achieve a parsimonious model for each plot image. No interaction terms were considered in the LR models. The best threshold value for each plot image was determined by evaluating the percent of the original input points that were correctly classified for all possible threshold values from 0.05 to 0.95 ranging in increments of 0.05 . The regression coefficients and variables from the final LR models were used to create a spatial layer of probability of belonging to the noncanopy class for each plot image. The threshold value was then used to split the probability surface into canopy and noncanopy classes (i.e., any pixel or object with a probability less than the threshold was assigned to the canopy class; those above or equal to the threshold were assigned to the noncanopy class).

For both the ML and LR classifications, validity of the final classifications for each plot image was assessed by calculating the percent of the 300 observer-evaluated points that were correctly classified and a kappa coefficient of agreement (Cohen 1968; Congalton 1991). Kappa ranges in value from -1.0 to 1.0 , but in practice values are constrained between 0.0 and 1.0 (negative values mean that the predictions are reversed). It measures the likelihood of observed agreement between two classifications (i.e., in this case, observed classes for a set or points vs. predicted classes) arising from chance. Kappa can be interpreted as the proportion by which an observed classification is better than a random classification (Lillesand and Kiefer 1994), and we considered kappa values of 0.5 or greater (i.e., $50 \%$ better than chance assignment of image pixels or objects to canopy and noncanopy classes) to reflect an acceptable amount of agreement between the two classifications.

\section{Calculation of Canopy Gaps From Images}

Canopy gaps were calculated from the four raster classifications of each plot image by first extracting the noncanopy class pixels or objects and converting them to polygons (Fig. 2B). The noncanopy polygons were intersected with lines repre- 
senting the virtual transects, and the length of each remaining transect segment was calculated. Virtual transects were located and aligned to match field transects to the extent possible (see Field Data Collection section). Noncanopy transect segments larger than $25 \mathrm{~cm}$ were considered canopy gaps, and the total proportion of all transect lines in three canopy gap sizes (25$50 \mathrm{~cm}, 50-200 \mathrm{~cm}$, and $>200 \mathrm{~cm}$ ) was calculated for each plot image (Fig. 2C).

\section{Field Data Collection}

For each $50 \times 50 \mathrm{~m}$ sampling plot, canopy-gap data were collected along six 50-m transects oriented north to south and evenly spaced across the plot. Plot corner locations were recorded using a differentially corrected global positioning system with submeter accuracy (GeoXT 2005, Trimble, Sunnyvale, CA). The start and stop distance along the transect was recorded for all canopy gaps larger than $20 \mathrm{~cm}$ following Herrick et al.'s (2009) protocol and the size of each canopy gap calculated. Canopy was defined as any $3-\mathrm{cm}$ segment of the transect that had at least $50 \%$ cover of live or dead plant material based on a vertical projection from the canopy to the ground. Litter (detached plant material) was not considered part of the plant canopy. Measurements for each plot were summarized as the proportion of the total plot transect length $(300 \mathrm{~m})$ in canopy gaps of the three different size classes $(25-$ $50 \mathrm{~cm}, 50-200 \mathrm{~cm}$, and $>200 \mathrm{~cm}$ ).

\section{Statistical Analysis of Canopy Gap Estimates}

Proportion of the transect in each of the three size classes as measured for each plot in the field was compared to estimates from the four-image classification techniques. The linear relationship between the field measurements of canopy gap and the image-based estimates was established via regression, and the strength of the association (i.e., coefficient of determination) and the slope of the regression line were evaluated ( $m$ command in R). Poor association between fieldand image-based estimates would suggest a method is not reliable for estimating canopy gap size distributions. Regression line intercepts different than zero and slopes different than one suggest that a method either over- or underestimates canopy gap proportions. Poor image classifications could obscure relationships between field- and image-based estimates. This could occur for several reasons such as difficulty in discriminating between grass cover and litter (considered noncanopy) when litter is abundant in a plot, poor image interpretation by the observers, or poor calibration of observers to the plots. In any case, poor classifications can be easily identified by their low kappa scores. For the purposes of comparison, we present results with all plots and results using only plots with classification kappa scores greater than 0.5. We conducted nonparametric analysis of variance (ANOVA) on kappa score ranks between each classification method and approach for each state, and followed this with pairwise comparisons to determine if there were significant differences between the fourimage classification techniques. Finally, for each image plot we calculated and plotted the Euclidean distance between the fieldand image-based canopy gap estimates using the three size classes as axes.

\section{RESULTS}

\section{Image Classification Assessment}

Generally, percent of input points correctly classified and kappa coefficients of agreement for plot image classifications were very high (Table 2). For New Mexico, ANOVA on kappa values for the different classification methods indicated a significant effects of classification method (ML classification vs. LR, $P=0.005$ ) and approach (object segmentation vs. pixel-based, $P=0.021$ ) at the $\alpha=0.05$ level. Pairwise comparisons showed that only kappa values for pixel-based LR and object-segmented ML classification were significantly different than each other at the $\alpha=0.05$ level $(P<0.001)$. This suggested that pixel-based LR yielded better classification of canopy vs. noncanopy for the New Mexico plots than did object-segmented ML classification. For the Nevada and Idaho plots, there was no significant difference in kappa coefficients between the classification methods $(P=0.390$ and $P=0.887$ for Nevada and Idaho, respectively).

In New Mexico, all plot image classification for all four methods had kappa coefficients greater than 0.5. For Nevada, one plot had kappa scores below 0.5 for both ML classification methods ( $\kappa=0.3844$ and $\kappa=0.0367$ for object-segmented and pixel-based ML classification, respectively). For Idaho, six plots had kappa coefficients below 0.5 for at least one method, and three of those plots had kappa coefficients below 0.5 for all four methods.

\section{Estimates of Canopy Gap Size Distributions}

We found a strong relationship between image- and field-based estimates of the total percent of the plot in canopy gaps greater than $50 \mathrm{~cm}$ (Table 3; Fig. 3). When considering all plots, higher coefficients of determination were found with the LR estimates than with ML classification. When poor classification plots $(\kappa<0.5)$ were excluded, $R^{2}$ values were all higher than 0.9 and similar for all methods. Slopes of regression lines between fieldand image-based estimates were different from one for both LR methods $(P=0.0012$ and $P<0.0001$ for object-segmented and pixel-based, respectively) and not significantly different from one for both ML classification methods $(P=0.0653$ and $P=0.1147$ for object-segmented and pixel-based, respectively) at the $\alpha=0.05$ level.

The relationship between field- and image-based canopy gap estimates varied with size class of the canopy gaps when all plots were included (Table 3; Fig. 3). Canopy gaps between $25 \mathrm{~cm}$ and $50 \mathrm{~cm}$ gave the weakest relationship $\left(R^{2}\right.$ between 0.439 and 0.772 ). Each method had a regression slope coefficient greater than one for this size class, indicating an underestimation of gaps of this size class by the image-based method. However, for the pixel-based LR method, the difference was not significant at the $\alpha=0.05$ level $(P=0.1836)$. For the $50 \mathrm{~cm}$ to $200 \mathrm{~cm}$ canopy gap size class, $R^{2}$ values were higher for all methods $\left(R^{2}\right.$ between 0.758 and 0.845$)$. For all image classification methods in this size class, regression slopes were not significantly different from one at the $\alpha=0.05$ level. The largest size class (canopy gaps $>200 \mathrm{~cm}$ ) saw the best relationship between field- and image-based canopy gap estimates $\left(R^{2}\right.$ between 0.954 and 0.969$)$. In this size class, regression slope coefficients for ML classification methods 
Table 2. Correspondence between the image-interpreter training data and the resulting canopy/noncanopy classifications. Percent of input observations correctly classified (\% Correct) and kappa coefficients of agreement (Cohen 1968) were summarized by site.

\begin{tabular}{|c|c|c|c|c|c|c|c|c|}
\hline & \multicolumn{4}{|c|}{ Logistic regression } & \multicolumn{4}{|c|}{$\mathrm{ML}^{1}$ classification } \\
\hline & \multicolumn{2}{|c|}{ Segmented } & \multicolumn{2}{|c|}{ Pixel-based } & \multicolumn{2}{|c|}{ Segmented } & \multicolumn{2}{|c|}{ Pixel-based } \\
\hline & $\%$ Correct & Kappa & $\%$ Correct & Kappa & $\%$ Correct & Kappa & $\%$ Correct & Kappa \\
\hline \multicolumn{9}{|l|}{ New Mexico } \\
\hline Mean & 92.76 & 0.8004 & 94.76 & 0.8546 & 89.76 & 0.7332 & 91.97 & 0.7872 \\
\hline SD & 2.79 & 0.0598 & 2.30 & 0.0537 & 4.11 & 0.0881 & 2.23 & 0.0597 \\
\hline Minimum & 87.37 & 0.6858 & 91.03 & 0.7715 & 79.86 & 0.5734 & 88.29 & 0.7213 \\
\hline Maximum & 97.96 & 0.8639 & 98.67 & 0.9867 & 93.56 & 0.8638 & 95.32 & 0.8924 \\
\hline \multicolumn{9}{|l|}{ Nevada } \\
\hline Mean & 93.77 & 0.7433 & 95.47 & 0.8077 & 86.51 & 0.6785 & 83.82 & 0.6621 \\
\hline SD & 5.03 & 0.1142 & 3.57 & 0.0973 & 18.74 & 0.2528 & 30.35 & 0.2789 \\
\hline Minimum & 84.62 & 0.5614 & 90.30 & 0.6080 & 38.44 & 0.0294 & 3.33 & 0.0004 \\
\hline Maximum & 98.68 & 0.9158 & 99.00 & 0.9301 & 97.35 & 0.8427 & 98.00 & 0.8820 \\
\hline \multicolumn{9}{|l|}{ Idaho } \\
\hline Mean & 92.88 & 0.4172 & 94.86 & 0.3412 & 83.41 & 0.3633 & 80.89 & 0.3911 \\
\hline SD & 6.97 & 0.3103 & 4.09 & 0.2985 & 16.48 & 0.2974 & 30.14 & 0.3103 \\
\hline Minimum & 78.41 & -0.0045 & 86.05 & 0.0000 & 53.29 & 0.0000 & 1.68 & 0.0000 \\
\hline Maximum & 98.99 & 0.7710 & 99.66 & 0.7144 & 99.66 & 0.6976 & 99.66 & 0.7171 \\
\hline
\end{tabular}

${ }^{1} \mathrm{ML}$ indicates maximum-likelihood; SD, standard deviation.

were not significantly different than one, but both LR methods were at the $\alpha=0.05$ level $(P=0.0003$ and $P<0.0001$ for object-segmented and pixel-based, respectively).

In all size classes and for all methods, image-based estimates of canopy gaps from plot images with low classification kappa scores were highly variable with respect to their field-based estimates (Fig. 4). In all cases, the relationship between field- and image-based estimates of canopy gaps improved when the low-kappa-score plots were excluded (Table 3). With large (i.e., $>200 \mathrm{~cm}$ ) canopy gaps, LR results were less affected by the poor classification images than ML classification.

Comparisons of the four methods within each canopy-gap size class showed that ML classification produced higher associations than LR between the field- and image-based canopy

Table 3. Associations between field-measurements of canopy gaps and estimates from four different image-analysis techniques. Results are presented for all plot images and for only those plot images with a kappa coefficient of agreement (Cohen 1960; Congalton 1991) $>0.5(n=20)$. Regression slope coefficients (Coef.) and standard errors (SEs) are from a linear regression between the field measurements and image estimates (plots with kappa >0.5) for each category.

\begin{tabular}{|c|c|c|c|c|}
\hline & \multicolumn{2}{|c|}{ Logistic regression } & \multicolumn{2}{|c|}{$\mathrm{ML}^{1}$ classification } \\
\hline & Segmented & Pixel-based & Segmented & Pixel-based \\
\hline \multicolumn{5}{|c|}{ Canopy and gaps $<50 \mathrm{~cm}$} \\
\hline$r^{2}$ all sites & 0.916 & 0.921 & 0.667 & 0.437 \\
\hline$r^{2}$ only $\kappa>0.5$ & 0.952 & 0.959 & 0.971 & 0.961 \\
\hline Coef. (SE) & $0.844(0.045)$ & $0.805(0.039)$ & $0.939(0.039)$ & $0.944(0.045)$ \\
\hline \multicolumn{5}{|l|}{ Gaps $25-50 \mathrm{~cm}$} \\
\hline$r^{2}$ all sites & 0.260 & 0.304 & 0.279 & 0.607 \\
\hline$r^{2}$ only $\kappa>0.5$ & 0.534 & 0.439 & 0.628 & 0.772 \\
\hline Coef. (SE) & $1.662(0.336)$ & $1.327(0.354)$ & $1.615(0.293)$ & $1.721(0.221)$ \\
\hline \multicolumn{5}{|l|}{ Gaps $50-200 \mathrm{~cm}$} \\
\hline$r^{2}$ all sites & 0.486 & 0.380 & 0.712 & 0.330 \\
\hline$r^{2}$ only $\kappa>0.5$ & 0.758 & 0.763 & 0.833 & 0.845 \\
\hline Coef. (SE) & $1.042(0.139)$ & $0.906(0.119)$ & $1.078(0.114)$ & $1.129(0.114)$ \\
\hline \multicolumn{5}{|l|}{ Gaps $>200 \mathrm{~cm}$} \\
\hline$r^{2}$ all sites & 0.941 & 0.858 & 0.654 & 0.474 \\
\hline$r^{2}$ only $\kappa>0.5$ & 0.954 & 0.955 & 0.969 & 0.966 \\
\hline Coef. (SE) & $0.825(0.043)$ & $0.792(0.041)$ & $0.972(0.041)$ & $0.956(0.042)$ \\
\hline
\end{tabular}

${ }^{1} \mathrm{ML}$ indicates maximum-likelihood. 


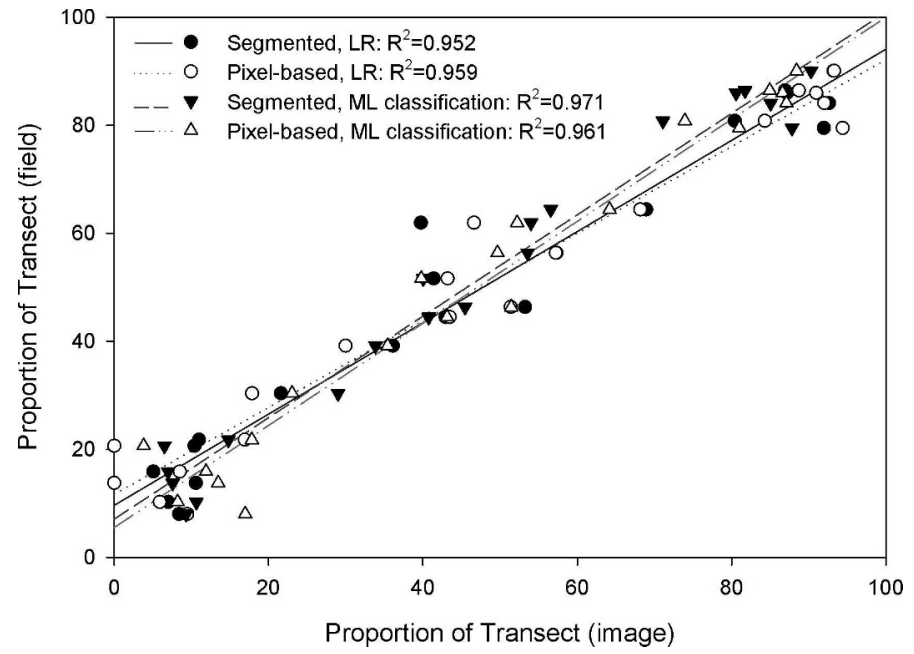

Figure 3. Relationship between field- and image-based estimates of proportion of total transect length in canopy gaps greater than $50 \mathrm{~cm}$. Results are presented only for plots with image classifications having kappa coefficients of agreement $>0.5$ for all methods. The dotted line represents a 1:1 relationship.

gap estimates in all size classes with low-kappa plots excluded (Table 3; Fig. 4). However, in the $50 \mathrm{~cm}$ to $200 \mathrm{~cm}$ and $>200 \mathrm{~cm}$ size classes, all four methods were generally very similar in their performance. In the $25 \mathrm{~cm}$ to $50 \mathrm{~cm}$ and $50 \mathrm{~cm}$ to $200 \mathrm{~cm}$ size classes, the regression slope coefficients were not significantly different at the $\alpha=0.05$ level. In the $>200 \mathrm{~cm}$ canopy-gap size class, however, the LR regression coefficients were significantly lower than the ML classification coefficients at the $\alpha=0.05$ level.

We plotted the field- and image-based estimates for each plot along three axes-canopy (including canopy gaps less than $50 \mathrm{~cm}), 50 \mathrm{~cm}$ to $200 \mathrm{~cm}$ canopy gaps, and canopy gaps $>200 \mathrm{~cm}$-in ternary plots for each of the four methods with lines illustrating the distance between the field- and imagebased estimate for each plot (Fig. 5). The ternary plots allowed us to compare the relative magnitudes and direction of differences between field- and image-based estimates by method. A large difference (longer line) would have greater ramifications for estimates of wind and water erosion models based on gap distributions than smaller differences (shorter line). The ternary plots show that the ML classification method generally produced smaller differences between field- and image-based estimates (Table 4).

We also found that the LR estimates tended to either overpredict proportions of large canopy gaps if there were some large canopy gaps present or underpredict canopy gaps in plots with high cover (Fig. 5). This was evidenced in the ternary graphs by the tendency for the image-based LR estimates of a plot to be closer to the graph corners than its corresponding field-based estimate. Conversely, image-based estimates using ML classification did not show any noticeable directional trend, which would be expected with a robust estimator.

\section{DISCUSSION}

Our results demonstrate that size distributions of canopy-gaps larger than $50 \mathrm{~cm}$ can be reliably estimated from HR imagery in a variety of plant community types. Association between the field- and image-based estimates increased as the size of the canopy gaps increased, which is to be expected as large canopy gaps are generally easier to discriminate in aerial photographs. We found that the ML classifications out-performed LR as a technique for estimating canopy gaps from HR imagery even though their classification accuracies and kappa coefficient scores were, on average, lower than those of LR. This could be an expression of LR overfitting the input data and creating classifications that were not as generally applicable as the ML classifications.

We found little difference between pixel-based and objectbased approaches even though previous studies have suggested that OBIA would perform better (e.g., Dorren et al. 2003; Yan et al. 2006; Karl and Maurer 2010a). In our study, we considered only one segmentation scale. However, studies on applications of OBIA have demonstrated that classification accuracy will vary with scale (Feitosa et al. 2006; Addink et al. 2007; Karl and Maurer 2010b). Consideration of other segmentation scales in our analysis may have resulted in better object-based results compared to the pixel-based analysis.

While there have not been many other published studies looking at estimating canopy gaps from imagery, our results are consistent with other studies that have estimated plant cover from HR and VHR imagery. Booth and Cox (2008) found that cover in shortgrass prairie could be estimated within $5 \%$ of field-based estimates using manual interpretation of VHR images with as few as 30 observations per image. They also found, though, that automated image classification techniques did not perform as well as manual image interpretation for estimating cover in their shortgrass prairie system. Luscier et al. (2006), however, found that an object-based classification of VHR images could estimate cover to within 1\% to $4 \%$ for different general land cover types (e.g., grass, shrub, and bare ground). Similarly, Duniway et al. (in press) found that manual point interpretation of general cover types (woody, herbaceous, and noncanopy) from HR imagery was consistently related to field-based estimates across a diversity of ecosystems.

Hansen and Ostler (2001) and Fensham et al. (2002) found overprediction in shrub cover increased as scale of imagery became smaller (i.e., image resolution became coarser) due to obscuring of edges of plants from larger pixel sizes. This phenomenon would also affect estimation of canopy gap size distributions by causing individual canopy gaps to appear smaller than they really are. In this study, we did not directly measure the ability to detect canopy edges from imagery. We would expect that delineation of canopy edges would increase as image resolution became finer, and that small canopy gaps would be most susceptible to errors in edge definition. This could partly explain our results for canopy gaps smaller than $50 \mathrm{~cm}$ and argues for using the highest-resolution imagery attainable for estimating vegetative cover and canopy gap size distributions. However, rather than automatically obtaining the highest-resolution imagery possible for estimating vegetation cover or canopy-gap size distributions, image resolution should be matched to the system being considered. In environments with clumpy vegetation and large bare ground patches (e.g., Fig. 1, New Mexico Site 1), coarser-resolution imagery may yield acceptable results, whereas in environments with different plant growth forms highly intermixed (e.g., 

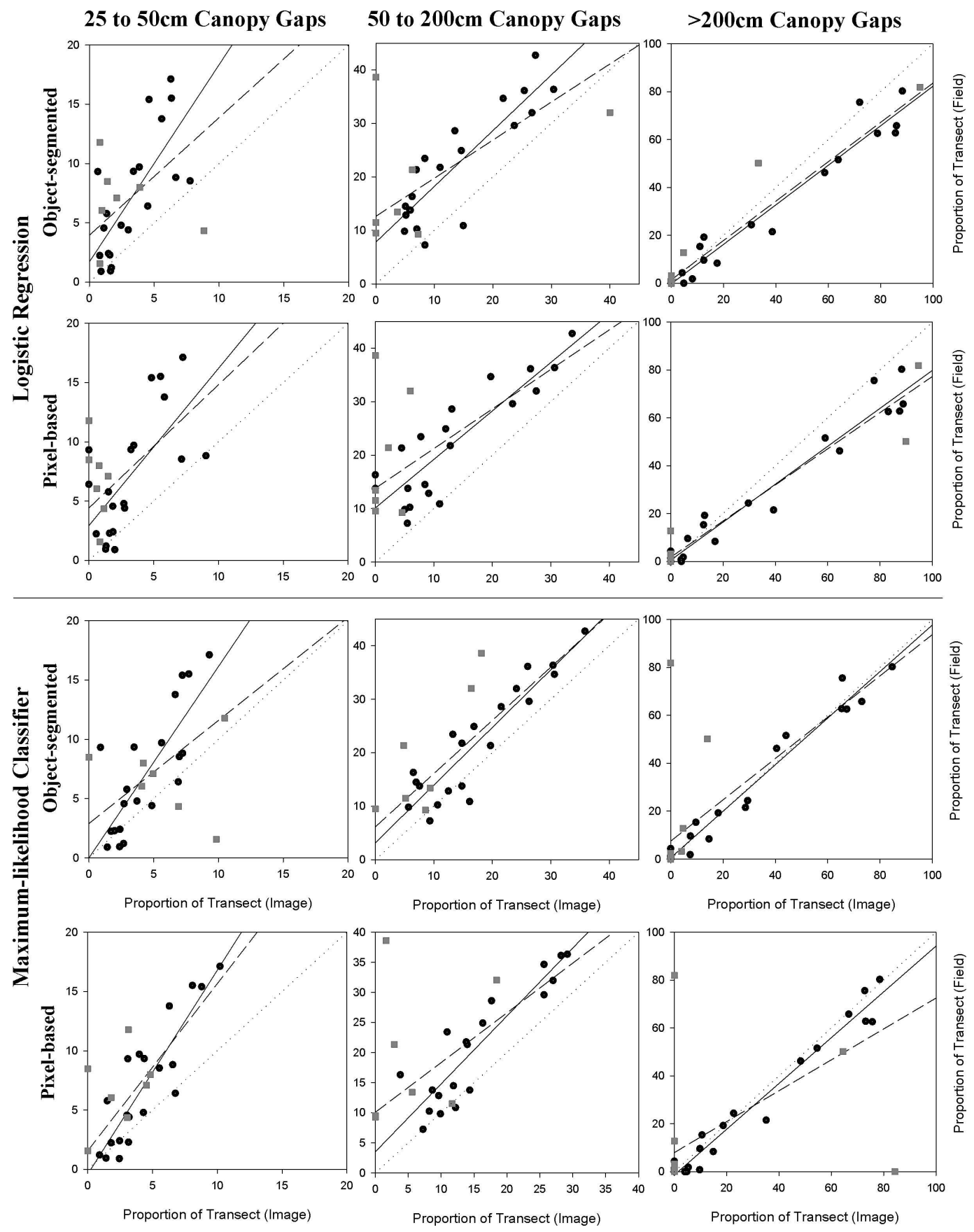

Figure 4. Comparison of image and field estimates of proportion of transect in three canopy gap sizes for the four different classification techniques. The dashed line is the regression line between field and image estimates for all plots. Gray squares represent plots with a classification kappa score of $<0.5$. The solid line is the regression line for plots with a kappa coefficient of agreement $>0.5$. Regression $R^{2}$ values are given in Table 3. The dotted line represents a 1:1 relationship.

Fig. 1, Idaho Site 2), finer-resolution imagery would be necessary to accurately estimate canopy gap size distributions.

Shadows in the imagery can also cause problems for detecting canopy edges and could lead to underestimation of canopy gaps when automated image classification techniques are used. While efforts were taken to minimize the effects of shadows in our images, some shadows did occur. When images are manually interpreted, the analyst can often determine the land cover class in a shadow and decide if a shadow should be considered canopy or noncanopy. In our image classifications, because we were using only two classes, shadows were generally classified as canopy. This could lead to an underestimation of canopy gaps. An alternative technique could be to classify shadows as a separate class and then attempt to subclassify the shadows into canopy and noncanopy.

In some cases, estimates of vegetation cover or canopy gaps from HR or VHR imagery may be more precise than estimates made in the field. Seefeldt and Booth (2006) found that imagebased estimates of vegetation cover in a sagebrush (Artemisia spp.) environment had equal or lower standard errors than 

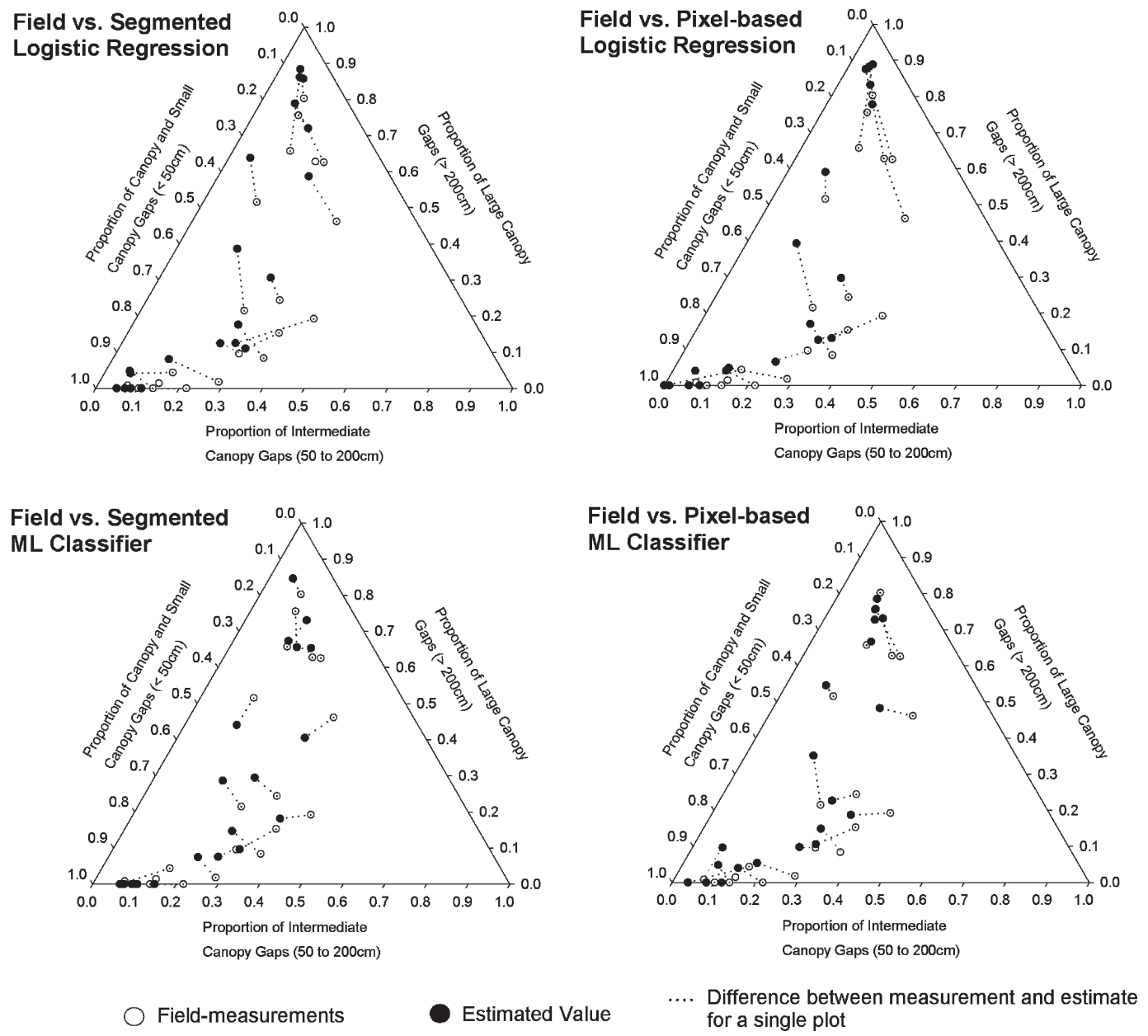

Figure 5. Ternary plots of all plots based on proportion of total plot transect length in 1) canopy and canopy gaps less than $50 \mathrm{~cm}$, 2) canopy gaps between $50 \mathrm{~cm}$ and $200 \mathrm{~cm}$, and 3) canopy gaps greater than $200 \mathrm{~cm}$. Black circles are estimated proportions from the different image classification techniques. The white circles represent the field-based estimates for each plot. Dashed lines show the Euclidean distance between the field-based and image classification estimates of canopy gaps.

field-based estimates from either ocular estimation or pointframe measurements. This type of result can occur if the size or density of vegetation make it difficult to place transects or sample frames within the plot in an unbiased fashion. Additionally, slope and landscape position can cause directional trends (i.e., anisotropy) in the shape, size, and distribution of noncanopy patches that can be difficult to detect from an oblique ground angle. Sampling canopy gaps without knowledge of such trends within a plot could lead to biased estimates. Image-based techniques, because the images are nadir-looking, have a better ability to detect anisotropy and adjust canopy gap measurements through different orientations of transects. Also, image-based estimation of canopy gaps opens up the possibility of making area-based canopy-gap estimates that take advantage of a richer set of features relevant to landscape ecology (e.g., shape, convolution, and patch size). Such metrics allow for directional estimates of run-off and water erosion (Ludwig et al. 2002; Ludwig et al. 2007) and wind erodability (McGlynn and Okin 2006). Further research is needed to relate these area-based canopy gap measurements to other ecological processes (e.g., wildlife habitat).

It is important to note that because we did not use a separate dataset for assessing the performance of the classifications, the values in Table 2 cannot be considered an accuracy assessment of the models but an expression of goodness-of-fit. Even so, these results are useful for identifying plots where it was

Table 4. Euclidean distances between field and estimated proportion of transects from the four different classification methods in three different canopy gap sizes: gaps $<50 \mathrm{~cm}$ gaps plus canopy cover, canopy gaps between $50 \mathrm{~cm}$ and $200 \mathrm{~cm}$, and canopy gaps $>200 \mathrm{~cm}$.

\begin{tabular}{lcccc}
\hline & \multicolumn{2}{c}{ Logistic regression } & & \multicolumn{2}{c}{ Maximum-likelihood classification } \\
\cline { 2 - 3 } \cline { 5 - 6 } & Segmentation & Pixel-based & Segmentation & 0.0962 \\
Mean distance & 0.1470 & 0.1562 & 0.1064 & 0.0980 \\
Median distance & 0.1439 & 0.1217 & 0.0410 & 0.1000 \\
Standard deviation & 0.0763 & 0.0872 & & 0.0569 \\
\hline
\end{tabular}


difficult to construct reliable predictions of canopy vs. noncanopy from image interpreter classification. Seven of our 27 plots had very low classification accuracies that resulted in our excluding them from our analyses. All seven of these plots had either high amounts of litter or low overall bare ground cover as measured in the field (Duniway et al. in press). Booth et al. $(2005 \mathrm{~b})$ reported difficulty in discriminating litter and bare ground in interpretation and classification of VHR imagery. While that may have contributed to the poor classifications we observed in these seven plots, a larger problem we experienced was confusion between grass and litter cover types. In assessment of canopy gaps, litter is not considered part of the plant canopy because it is subject to movement by wind and water and does not provide forage or habitat for most wildlife and livestock species (Herrick et al. 2009). From the standpoint of image interpretation, however, litter and senescent grasses look similar and can be difficult to reliably discriminate. Other factors could also contribute to confusion between classes including poor observer interpretation of the images and bad training and calibration of the observers.

Regardless of which classes are being confused, the result is a poor relationship between the observers' interpretations and the image data. The kappa coefficient of agreement is a metric of the strength of this relationship and was useful in separating plots where we could successfully estimate canopy gap size distributions from those where we could not. Having an objective means for identifying plots that likely have poor point classifications opens up an opportunity to explore more fully the causes of and possible remedies for classification difficulties. An advantage to using the kappa coefficient in this manner is it is based solely on the relationship between the observers' interpretations and the image data and does not require independent field data to identify locations where estimation of canopy gaps will be difficult. Thus, we recommend the use of classification goodness-of-fit measurements such as kappa coefficients be included routinely in estimation of canopy gaps from HR or VHR imagery.

\section{MANAGEMENT IMPLICATIONS}

We consider the approach described above as a semiautomated technique for deriving canopy-gap estimates from HR imagery. We conclude that classification of HR imagery based on observer-interpreted training points and ML classification is a viable technique for estimating canopy gap size distributions. Our results are consistent with other research that has looked at the ability to derive vegetation cover estimates from HR or VHR imagery using manual, semiautomated, and fully automated techniques. Additionally, we suggest that classification goodness-of-fit measures are a potentially useful tool for identifying and screening out plots where precision of estimates from imagery may be low, and this should be more rigorously investigated.

Many studies have touted the cost-effectiveness of deriving ecosystem indicators from HR and VHR imagery (e.g., Seefeldt and Booth 2006; Booth and Cox 2008). While this may be true for single indicators, cost effectiveness of HR image-based techniques will increase in general as we develop techniques to extract additional indicators from the same image. Also, archives of HR imagery will provide a rich source of data that can be mined as new techniques are developed. The availability of HR imagery is constantly increasing, and our ability to store, distribute, and analyze these images is also increasing faster than information can be extracted from them by fully manual interpretation methods. To meet the requirements of monitoring vast landscapes at scales fine enough to inform management decisions, more research and development is needed into semiand fully automated techniques for deriving precise estimates of ecosystem indicators from this rich supply of data.

\section{LITERATURE CITED}

Addink, E. A., S. M. de Jong, and E. J. Pebesma. 2007. The importance of scale in object-based mapping of vegetation parameters with hyperspectral imagery. Photogrammetric Engineering and Remote Sensing 73:905-912.

Bautista, S., A. G. Mayor, J. Bourakhouadar, and J. Bellot. 2007. Plant spatial pattern predicts hillslope semiarid runoff and erosion in a Mediterranean landscape. Ecosystems 10:987-998.

Bestelmeyer, B. T., A. J. Tugel, G. L. Peacock, Jr., D. G. Robinett, P. L. Shaver, J. R. Brown, J. E. Herrick, H. Sanchez, and K. M. Havstad. 2009. State-andtransition models for heterogeneous landscapes: a strategy for development and application. Rangeland Ecology \& Management 62:1-15.

BLASCHKE, T. 2010. Object based image analysis for remote sensing. ISPRS Journal of Photogrammetry and Remote Sensing 65:2-16.

Bоoth, T. D., AND S. E. Cox. 2008. Image-based monitoring to measure ecological change in rangeland. Frontiers of Ecology and the Environment 6:185-190.

Booth, T. D., S. E. Cox, C. Fifield, M. Phillips, and N. Williamson. 2005a. Image analysis compared with other methods for measuring ground cover. Arid Land Research and Management 19:91-100.

Bоoth, T. D., S. E. Cox, And D. E. Johnson. 2005b. Detection-threshold calibration and other factors influencing digital measurements of ground cover. Rangeland Ecology \& Management 58:598-604.

Booth, T. D., And P. T. Tueller. 2003. Rangeland monitoring using remote sensing. Arid Land Research and Management 17:455-467.

Burnett, C., ANd T. BlaschKe. 2003. A multi-scale segmentation/object relationship modelling methodology for landscape analysis. Ecological Modeling 168:233-249.

Cohen, J. 1960. A coefficient of agreement for nominal scales. Educational and Psychological Measurement 20:37-46.

CoHen, J. 1968. Weighted kappa: nominal scale agreement with provision for scaled disagreement or partial credit. Psychological Bulletin 70:213-220.

Congalton, R. G. 1991. A review of assessing the accuracy of classifications of remotely sensed data. Remote Sensing of the Environment 37:35-46.

Dorren, L. K. A., B. Maier, And A. C. Selumonsbergen. 2003. Improved landsat-based forest mapping in steep mountainous terrain using object-based classification. Forest Ecology and Management 183:31-46.

Duniway, M. C., J. W. Karl, S. Schrader, N. Baquera, and J. E. Herrick. Rangeland and pasture monitoring: an approach to interpretation of high-resolution imagery focused on observer calibration for repeatability. Environmental Monitoring and Assessment. (in press). doi:10.1007/s10661-011-2224-2

Feitosa, R. Q., G. A. O. P. Costa, T. B. Cazes, and B. Feljo. 2006. A genetic approach for the automatic adaption of segmentation parameters. In: S. Lang, T. Blaschke, and E. Schopfer [EDS.]. First International Conference on Objectbased Image Analysis. Salzburg, Austria: Salzburg University.

Fensham, R. J., R. J. Falrfax, J. E. Holman, and P. J. Whitehead. 2002. Quantitative assessment of vegetation structural attributes from aerial photography. Internation Journal of Remote Sensing 23:2293-2317.

Fox, T. J., M. G. Knutson, And R. K. Hines. 2000. Mapping forest canopy gaps using air-photo interpretation and ground surveys. Wildlife Society Bulletin 28:882-889

GILletTE, D. A. 1977. Fine particulate-emissions due to wind erosion. Transactions of the Asae 20:890-897. 
Hansen, D. J., and W. K. Ostler. 2001. An evaluation of new high-resolution image collection and processing techniques for estimating shrub cover and detecting landscape changes. Proceedings of the 18th Biennial Workshop of Color Photography and Videography in Resource Assessment; 16-18 May 2001: Amherst, MA, USA. Amherst, MA, USA: The American Society for Photogrammetry and Remote Sensing, University of Massachusetts, Amherst.

Herrick, J. E., V. Lessard, K. E. Spaeth, P. Shaver, R. S. Dayton, D. A. Pyke, L. Jolley, AND J. J. Goebel. 2010. National ecosystem assessments supported by scientific and local knowledge. Frontiers of Ecology and the Environment 8:403-408.

Herrick, J. E., J. W. Van Zee, K. M. Havstad, L. M. Burkett, and W. G. Whitford. 2009. Monitoring manual for grassland, shrubland, and savanna ecosystems. Las Cruces, NM, USA: USDA-ARS Jornada Experimental Range. $236 \mathrm{p}$.

Hunt, E. R. JR., J. H. Everitt, J. C. Ritchie, M. S. Moran, T. D. Booth, G. L. Anderson, P. E. Clakk, and M. S. Seyfri [eds.]. 2003. Applications and research using remote sensing for rangeland management. Photogrammetric Engineering and Remote Sensing 69:675-693.

KARL, J. W. 2010. Spatial predictions of cover attributes of rangeland ecosystems using regression kriging and remote sensing. Rangeland Ecology \& Management 63:335-349.

KarL, J. W., AND B. A. Maurer. 2010a. Multivariate correlations between imagery and field measurements across scales: comparing pixel aggregation and image segmentation. Landscape Ecology 24:591-605.

KarL, J. W., AND B. A. Maurer. 2010b. Spatial dependence of predictions from image segmentation: a variogram-based method to determine appropriate scales for producing land-management informatino. Ecological Informatics 5:194-202.

Knapp, P. A., P. L. Warren, and C. F. Hutchinson. 1990. The use of large-scale aerial photography to inventory and monitor arid rangeland vegetation. Journal of Environmental Management 31:29-38.

Laliberte, A. S., and A. Rango. 2009. Texture and scale in object-based analysis of subdecimeter resolution unmanned aerial vehicle (UAV) imagery. IEEE Transactions on Geoscience and Remote Sensing 47:761-770.

Laliberte, A. S., A. Rango, K. M. Havstad, J. F. Paris, R. F. Beck, R. McNeely, and A. L. Gonzalez. 2004. Object-oriented image analysis for mapping shrub encroachment from 1937 to 2003 in southern New Mexico. Remote Sensing of the Environment 93:198-210.

LILleSAND, T. M., AND R. W. KIEFER. 1994. Remote sensing and image interpretation. New York, NY, USA: John Wiley \& Sons. 750 p.

Ludwig, J. A., G. N. Bastin, V. H. Chewings, R. W. Eager, and A. C. Liedloff. 2007. Leakiness: a new index for monitoring the health of arid and semiarid landscapes using remotely sensed vegetation cover and elevation data. Ecological Indicators 7:442-454.
Ludwig, J. A., R. W. Eager, G. N. Bastin, V. H. Chewings, and A. C. Liedloff. 2002. A leakiness index for assessing landscape function using remote sensing. Landscape Ecology 17:157-171.

Luscier, J. D., W. L. Thompson, J. M. Wilson, B. E. Gorham, and L. D. Dragut. 2006. Using digital photographs and object-based image analysis to estimate percent ground cover in vegetation plots. Frontiers of Ecology and the Environment 4:408-413.

Marsett, R. C., J. Qı, P. Heilman, S. H. Beidenbender, M. C. Watson, S. Amer, M. Weltz, D. Goodrich, and R. Marsett. 2006. Remote sensing for grassland management in the arid southwest. Rangeland Ecology \& Management 59:530-540.

McGLYnN, I. O., AND G. S. OKIN. 2006. Characterization of shrub distributions using high spatial resolution remote sensing: ecosystem implications for a former Chihuahuan Desert grassland. Remote Sensing of Environment 101:554-566.

Milton, S. J., W. R. J. Dean, M. A. Du Plessis, and W. R. Siegfri [eds.]. 1994. A conceptual model of arid rangeland degradation. BioScience 44:70-76.

National Research Council. 1994. Rangeland health: new methods to classify, inventory, and monitor rangelands. Washington, DC, USA: National Academy Press. 180 p.

Natural Resources Conservation Service. 2006. Land resource regions and major land resource areas of the United States, the Caribbean, and the Pacific Basin. Washington, DC, USA: US Department of Agriculture. 669 p.

Nusser, S. M., And J. J. Goebel. 1997. The National Resources Inventory: a longterm multi-resource monitoring programme. Environmental and Ecological Statistics 4:181-204.

OKIN, G. S. 2008. A new model of wind erosion in the presence of vegetation. Journal of Geophysical Research 113:F02S10.

Pierson, F. B., W. H. Blackburn, S. S. Vanvactor, and J. C. Wood. 1994. Partitioning small-scale spatial variability of runoff and erosion on sagebrush rangeland. Water Resources Bulletin 30:1081-1089.

Royston, J. P. 1982. An extension of Shapiro and Wilk's W test for normality to large samples. Applied Statistics 31:115-124.

Schlesinger, W. H., J. F. Reynolds, G. L. Cunningham, L. F. Huenneke, W. M. Jarrell, R. A. Virginia, ANd W. G. Whitford. 1990. Biological feedbacks in global desertification. Science 247:1043-1048.

SeEfeldT, S. S., And T. D. Booth. 2006. Measuring plant cover in sagebrush steppe rangelands: a comparison of methods. Environmental Management37:703-711.

Wang, L., W. P. Sousa, And P. Gong. 2004. Integration of object-based and pixelbased classification for mapping mangroves with IKONOS imagery. Internation Journal of Remote Sensing 25:5655-5668.

Yan, G., J. F. Mas, B. H. P. Maathuis, Z. Xiangmin, and P. M. Van Dijk. 2006. Comparison of pixel-based and object-oriented image classification approaches: a case study in a coal fire area, Wuda, Inner Mongolia, China. International Journal of Remote Sensing 27:4039-4055. 